\title{
The Impact of Work-Family Supportive Supervisors on Job Involvement and Job Satisfaction with Career Competencies as an Intervening Variable
}

\author{
Suharnomo ${ }^{1, *}$, Paguh Raja Johnpray ${ }^{2}$ \\ ${ }^{1}$ Department of Management, Faculty of Economics and Business, Diponegoro University, Semarang - Indonesia \\ 2 Department of Management, Faculty of Economics and Business, Diponegoro University, Semarang - Indonesia
}

\begin{abstract}
This study was conducted to explore the relationship between work-family supportive supervisor, career competencies, job involvement, and job satisfaction. Data were collected from a sample of 162 respondents who worked as a nurse at hospital in Jakarta, Indonesia. This study used Structural Equation Modeling (SEM) to examine and estimate the relationship between the constructs. The study results indicate that work-family supportive supervisor has a positive and significant impact on career competencies, career competencies have a positive and significant impact on job involvement, and on job satisfaction. Work-family supportive supervisor has a positive and significant impact on job involvement and on job satisfaction. A total of 162 respondents with a percentage of $96.30 \%$ women showed that women need good support and policies in achieving a balance between work and family. Finally, this study highlights the importance of work-family supportive supervisor and career competencies for improving job involvement and job satisfaction. This study provides insights on how the human resources department can retain qualified staff and develop employee satisfaction.
\end{abstract}

\section{Introduction}

Unbalanced problem between life and work receives considerable attention from the human resources department, because the current workforce is owned by Gen-Y generation. Gen-Y's generation is the generation that considers quality of life as their top priority. The generation was born in the 1970s until the early 1990s. Research in 2013 in China showed employees above 30 years suffered from extreme stress, where the survey shows more than $64 \%$ of employees below 35 years get three main pressures which are the conflict with the balance of life and work, study pressure, and the pressure of competition [1]. In the western countries, reaching equality between life and work is used as a management tool of strategic human resources to maintain quality staff $^{2}$. In addition, most of employees below 30 years and become the only child in their family, have an obligation to take care of their parents, especially when their parents get disease. As a result of marriage, work (job), and family, becomes a source of considerable pressure for employees below 30 years. These people need work-family-friendly policy and endowment.

Work-family supportive supervisor is a supervisor who supports subordinate to participate in formal role that existed in family, and gives information and suggestion about how a certain job could decrease a problem that related with family responsibilities. Workfamily supportive supervisor is a signal to employee that proved they got an appreciation, an important coping source psychologist and also a buffer of tension, or a human resources protection. Similar with general supervisor's support, but supervisor whose support family more having positive relation with in-role job performance because of enhancement quality of human resource also contextual performance and obligation which perceived by an employee as an mutual relation. In this case, work-family supportive supervisor considered as a part of internal relation between employee, where supervisor should maintain good relationship with their subordinate in order to create favorable atmosphere in the working's life. Work-family supportive supervisor has a strong relationship with other variable such as career competencies [2].

Career competencies is a characteristic which can be measured, usually relative stable of individual whose can predict superior performance such as strategic orientation, business knowledge, technical ability, and teamwork. Career competencies is a figuration professional competency which owned by employee because of supervisor support in case of motivation and giving positive direction to the employee in case of working. Career competencies is becoming an important thing in working atmosphere, which is also getting more

\footnotetext{
*Corresponding author: suharnomo.undip@gmail.com; suharnomo@live.undip.ac.id
} 
dynamic now on. Career competencies could be classified into 3 types, "knowing-why, knowing-whom, and knowing-how". Career competencies have an impact to job involvement and job satisfaction of an employee in company. The number of employee, who less support from supervisor is getting increase more pressure in working life, then human resource party should retain qualified staff by knowing level of employee's work satisfaction to the job and employee's courage level to be involved in a certain job with their owned career competencies.

Job involvement as an internalization values about good jobs or importance job for existence of person. Job involvement is a personal level of job performance affects their dignity and level of physiology in case of identification their selves to the job or the importance of job in personal reflection. Personal who has high involvement is more identified their selves to the job and assume a job as the most important thing in their life. In the end, every effort which is done by human resources department in retaining qualified staff, especially employee' competency development, and applied a policy which is supporting to work-family conflict with supervisor who also supports that, will cause higher level of employee job satisfaction

Job satisfaction is an affective or emotional response reaction from a job, a condition which someone could feel a satisfaction in one and another aspects. It stated that job satisfaction is a positive feeling about a job which can be a result of evaluation from several job characteristic. One of many indicator of job satisfaction is supervisor's satisfaction. Research proved that level of satification can be diverse, depend on aspect that job satisfaction viewed.

Competition which made the employees to increase their capabilities and competencies, confiscate their time and the need of balance between work and family. Hospital as a place where a person needs careness and protection is now beginning to compete closely in the selection of employees, services provided, and the development of its employees. Nurse is an employee who must give a full attention to each condition and time, also require attention for its work. As the nurse provides care to patients, they also requires attention such as policy and regulatory support for any problems that occur both in work and family. Therefore, this study aimed to explore the effect of the work-family supportive supervisor at the career competencies and its influence on job involvement and job satisfaction.

\section{Previous Researches}

Work-family supportive supervisor is someone who sympathized with employee's desire to find equilibrium between work and family responsibilities ${ }^{4}$. Work-family supportive supervisor is an informal adjustment demands and work scheduling along with suggestions about coping strategies provided by supervisors who support families who allow employee to meet their family responsibilities without unduly limiting their opportunity to fulfill their work's need. According to Greenhouse et al in Kong [1] there are seven measurements that need to be considered in work-family supportive supervision, which are :

Work-family supportive supervisor are:

1. Family supportive supervision

2. Family-supportive organizational perceptions

3. Spousal support

4. Work interference with family/WIF

5. Family interference with work/FIW

6. Work-family balance

7. Control and presence of children

Based on considered measurements above, could identified that several factors related to supervisor supports will be able to affect the way emloyee fulfill their work responsibility and family, so will get better work performance. Work-family supportive supervisor has a strong relationship with the career competencies and job involvement. Therefore, it could be seen that work-family supportive supervision could affect career competencies 5 .

Research conducted by Akkermans [3] concluded that the role of career competency role as a mediator. Results showed that career competencies positive associated with job resources and job involvement, but not (negatively) to the demands of work and emotional exhaustion. In addition, career competencies have mediated effect on the relationship between job demands and job involvement, and job resources have the effect of partially mediators in relations between career competencies and job involvement.

According to Akkermans et al. [3], career competencies is a knowledge, skills, and ability to develop career that could be affected by individual. It means that career competencies is getting more important and became requirement to navigate career. Career competencies defined as a valuable competencies for all employees, which that competencies become career development for themselves, regardless of certain jobs. Career competencies also refer to characteristic that describe behavior patterns, personal characteristics, self-concept, values, knowledge or expertise that brought by someone who performs superior (superior performer) in the workplace. This is about personality characteristic regarding their ability and the way they do it. Competencies is found in people whose classified as superior performers or effective. There are 6 important measurement which affect to career competencies, such as ;

\section{Reflection on motivation \\ 2. Reflection on qualities \\ 3. Networking \\ 4. Self-Profiling \\ 5. Work-exploration \\ 6. Career control}

Research about work-family supportive supervisor also found that work-family supportive supervisor has a positive contribution to the career competencies, job involvement and job satisfaction. Moreover, this discovery indicates that work-family supportive supervisor not only helps to retain qualified staff but also increases employee's job involvement and job satisfaction. In the end, the manager is obliged to listen 
to employees and appreciate the differences and needs of employees. "Such an organizational climate interference would help employees balance between work and family domains, have high job satisfaction and well-being, and ultimately serve customers happy." The outline research above explained how a good climate organization can help frontline employees to resolve problems that occur in the balance of family and work, with its impact on job satisfaction as well as satisfaction of service perceived by the customer to the frontline employees [1].

Job satisfaction is a matter that can be said as the level of happiness or the extent to which employees feel satisfied with what he/she has resolved in his/her work. It depends on key factors in job satisfaction itself. One of the factors most often discussed is the supervisor. When employee work, employee work not only for himself, but for the company, and his supervisor. Employees are required to take full responsibility to supervisor. In this relation, the relationship between the employee and the supervisor will be established stronger. It means, the relationship shows a positive/strong inclination on the side or even to strain that occurs due to the lack of effective communication. Employees who are married, and have children of course also became a problem itself, well it needs the support of supervisors as motivation in the work.

Job involvement can be explained as involvement about internalization values regarding job righteousness or the importance of individual's work value. Most of researchers agreed, that the fact of job involvement is building a different construction related, encompass of: organization commitment, job satisfaction, and intrinsic motivation. Good relation from supervisor to employee will increase employee's willingness to be involved in a job, especially to employee that already had family where their concentration to work will be split to their family affairs. If there are good relation between supervisor and employee, so family affairs wouldn't be a significant constraint

Beside of research job involvement and satisfaction, the important of work family supportive supervisor also reflected in research about work family conflict. Workfamily conflict is a form of inter-role conflict in which pressures from the work role are incompatible with pressures from the family role, and this conflict can have an important effect on the quality of both work and family domains [2]. This happen because of role pressure incompatibility exists when participation in one role is made more difficult by virtue of participation in another role. As such, the requirements of one role make performance of the other role more difficult, so that commitment to succeed in one role may heighten the concern for succeeding in another role. This implies that the amount of time a workers devotes to progress and succeeding in a chosen career interferes with handling family-work-related responsibilities. Specifically, the additional family-role activities required for nurses who struggle to balance the demands of work and home life as they attempt to manage simultaneous work and family domain pressures. Good level of job satisfaction and job involvement will be able to reduce possibility of work family conflicts, which could degrade workers's performance

The importance of work-family supportive supervisor also consider in the policies making when the manager can identify the policy that support employee and family, it will increase and satisfaction and work-family enrichment, which can lead to performance.

\section{The relationship between Work Family Supportive Supervisor and Career Competencies}

Supervisor can maximize the success of career and career networking. Individuals who are devoted to the career management, finally reach the highest career competencies, because they have a high-quality family, and supportive management. Work-family supportive supervisor has a positive influence on the career competencies [1].

In addition, research found that work-family supportive supervisor has an influence on the career competencies. The presence of supervisors who support a family, and work (work-family supportive supervisor) is the organization's efforts to maintain their job responsibilities and families. Activities that support organizations reduce employee's stress experience of work-family conflicts, and contribute to the highest productivity of the employees [4].

Research found that work-family supportive supervisor has a positive influence on the career selfefficacy. Career self-efficacy is a person's belief in his ability in the process of managing, developing and completing a career, to achieve the goal of his career. There are several factors that influence the career selfefficacy, which one is the condition of the family, and personality. If an employee who has a dual role as workers and housewives, and she is not able to meet the demands of both roles, there will be conflict-called work-family conflict [5].

Research [6] also revealed that work-family supportive supervisor had a shape that is supportive policies (policy support). This policy needs to be applied with the basis of any form of appreciation and concerns the company/organization to its employees. The support of work-life policies were a form of policy and the attention given by the company to its employees to provide convenience and comfort within the scope of private life that have an impact on working life. So that, it reduces the various clashes and supports of all aspects on the work, and as a result it will increase the career competencies and work commitments [7].

Work-family supportive supervisor has a positive and significant impact on the career competencies. Supervisory support has a positive relation to job satisfaction of employees and families, with the help from a supervisor who supports the employees. It can balance the life and work, and concentrate on the competence and career management [2].

H1: There is a positive relationship between the workfamily supportive supervisors with career competencies. 


\section{The Relationship between Career Competencies and Job Involvement.}

Individuals with high competencies' career tend to achieve a high level of job involvement, because "knowing why" career competency can inspire the internal motivation of employees. Employees with a high enough internal motivation tend to be involved in their work, because they have the inner desire to devote more effort to their work. Results from this study showed career competencies have a positive influence on job involvement [1].

In addition, individuals with high career competencies can rise to higher levels of performance work by proposing creative suggestions, develop additional skills, and introducing new practices. Employees with high scores in performance usually obtain a relatively higher level of assessment performance compared with colleagues from supervisors/managers of them. In turn, high appraisal can encourage employees to involve more in their job.

Career competencies have a positive influence on job involvement. Where an employee who knows what their value and strength, and better in making action plans and goals settings, can develop themselves and consequently, suffered in job involvement. They actively communicate with others and create opportunities associated with career where it creates a positive and energetic working environment that make employees engaged in their work.

When employees feel that their jobs can meet the need to acquire competence, it can encourage them a sense of satisfaction to exert more effort, and thereby it increases the involvement of their work (job involvement) [8].

H2: There is a positive relationship between career competencies and job involvement

\section{The relationship between Career Competencies and Job Satisfaction}

Research found that career competencies have influence on job satisfaction. Employees with high scores on the career competencies reached a high level of career satisfaction and job satisfaction. Employees who are satisfied with their careers can psychologically identify their career with their current job [1].

Career competencies have a positive influence on job satisfaction. People with high career competencies "know why, "know who", and" "know how" can set their career goals, and develop skills associated with the job. For example, people who get a high score on the " know why " competence, usually have realistic career expectations, knowledge of their strengths and weaknesses, and specific career goals. People who know themselves well showing a very strong career identity.

People who have a strong career identity and career competencies tend to seek regular training, acquiring portable skills, and building a network. Besides knowing how performance improves confidence and identity work. It can allow an individual to remodel his career. Given the unstable employment situation and the need to be always aware, is a way to develop new skills to set up. It is estimated that the "knowing how" competence is an important predictor of job satisfaction and career satisfaction [9].

H3: There is a positive relationship between career competencies and job satisfaction

\section{The relationship between Work-Family Supportive Supervisor and Job Involvement and Job Satisfaction}

Job satisfaction can be defined as a state affective resulting from the evaluation of a person from his job. When the hotel's employee found that their supervisor gives attention to their problems and provides sufficient support for the resolution to these problems, they become more satisfied in their work. These results found that there is a positive influence of the work-family supportive supervisor on job satisfaction [10].

Moreover, this research is also supported by research [11] where supportive supervisors has a positive and significant impact on job satisfaction of the server/ food waiters. Sergeant and Frenkel [12] found evidence in his research on call centers that work-family supportive supervisor has a positive and significant effect to job satisfaction frontline officer. Support of supervision has a significant and positive impact on job satisfaction frontline officer of the bank [13].

Work-family supportive supervisor has influence on the job involvement. When employees feel their supervisor supports their family, they tend to feel more comfortable psychologically, and devote themselves to their work. Psychological climate, such as management support became a positive contribution to job involvement and job satisfaction bank [1].

Based on the results of data analysis in research Siahaan (2011) obtained the value of $\mathrm{r} x y=0395$, Rsquare $=0156(p<0.05)$, which means that the quality of work life is proven to have a significant positive relationship to job involvement and accounted for 15 , $6 \%$ of the increase in job involvement on the subject of research. The results also showed that the majority of research subjects have high levels of quality of work life and job involvement is classified in the category of medium. This proves that the strong support from the supervisor, and the policies of the pro-work-family issues is needed.

H4: There is a positive relationship between the workfamily supportive supervisor with job involvement.

H5: There is a positive relationship between the workfamily supportive supervisor with job satisfaction. 


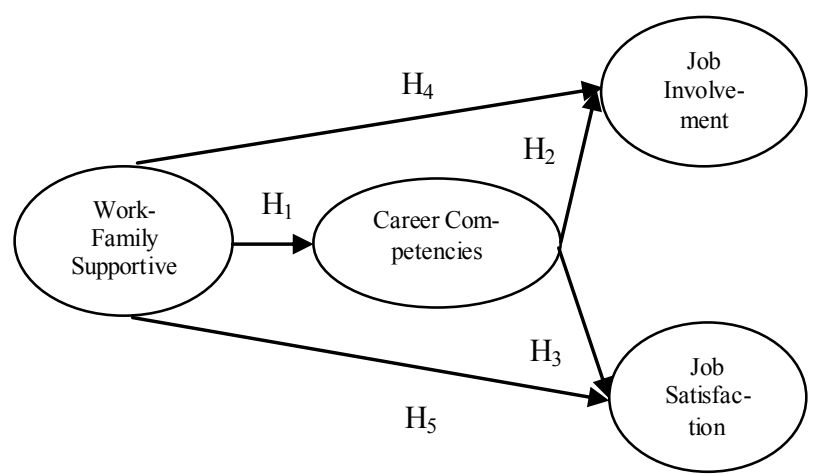

Figure 1. Theoretical Framework

\section{Reserach Methods}

\subsection{Sample}

Samples are a part of the number and characteristics owned by population [14]. There are some guidelines for determining the number of samples according to Ferdinand. One of them in the analysis of SEM (Structural Equation Modeling) requires a sample of at least 5 times the number of indicators used. This study uses 17 indicators. The sample selection was done because researchers have understood that the required information can be obtained from a specific target group that is able to provide the desired information because they have the information like that and they meet the criteria set by the researchers [15]. Type of purposive sampling is judgment sampling. These samples were selected by using certain considerations that are tailored to the purpose of research or research issues developed. Nurses are being sampled in this study were nurses PGI Cikini Hospital in Jakarta who still have family, this means that nurses still have relatives/parents /husband/wife and children.

Nurses who still have family are believed to still have a problem between work and family balance. In this study, nurses who still have family are believed to be able to support the research into work-family supportive supervisor and career competencies as variables that affect job involvement and job satisfaction.

A researcher must examine in detail of all members of the population. The next stage is to determine the number of samples of the population. The study population consisted of all nurses PGI Cikini Hospital in Jakarta. After known the population, the next is statistics determining (traditional statistical model), based on a statistical formula approach formula Yamane [15]. This study uses a slovin formula:

$$
\mathbf{n}=\frac{\mathbf{N}}{1+\mathbf{N}^{2}}
$$

Specification:

$\mathrm{N}=$ Number of samples

$\mathrm{N}=$ Population size

$\mathrm{D}=$ Precision expected or percentage of leeway inaccuracy due to sampling error can be tolerated or desirable.

Amount of population is 272 , and the desired error rate is $5 \%$, then the number of samples used are:

$$
N=272 / 272\left(0.05^{2}\right)+1=161 \text { employees/nurses }
$$

\section{Methods}

Methods of collecting primary data in this study was conducted using questionnaires. Questionnaires are a number of written questions to be answered by the survey respondents, so that researchers obtain empirical data to solve the problem of research and testing hypotheses that have been established. There are two types of questionnaires, which assists people and selfadministered. Data analysis is the process of simplification of data into a form that is easier to read and implement. Data analysis was performed with the aim to present empirical findings in the form of descriptive statistics that describe the characteristics of respondents and inferential statistical analysis that used to test the hypothesis proposed research [15].

Confirmatory factor analysis was conducted to test the validity of a theoretical construct, or in other words, whether the indicators used are uni-dimension size of a latent constructs. In accordance with the model developed in this study, the data analysis technique used is Structural Equation Modeling which is operated by AMOS program 20. Researchers used SEM analysis tool because it can directly analyze the relationship between the dependent variables with several independent variables, so that it help to take a decision which will be applied in the future.

\section{Results and Decision}

Analysis of Structural Equation Modeling (SEM) with a full model had been done to test the model and hypothesis. SEM analysis results are as follows: 


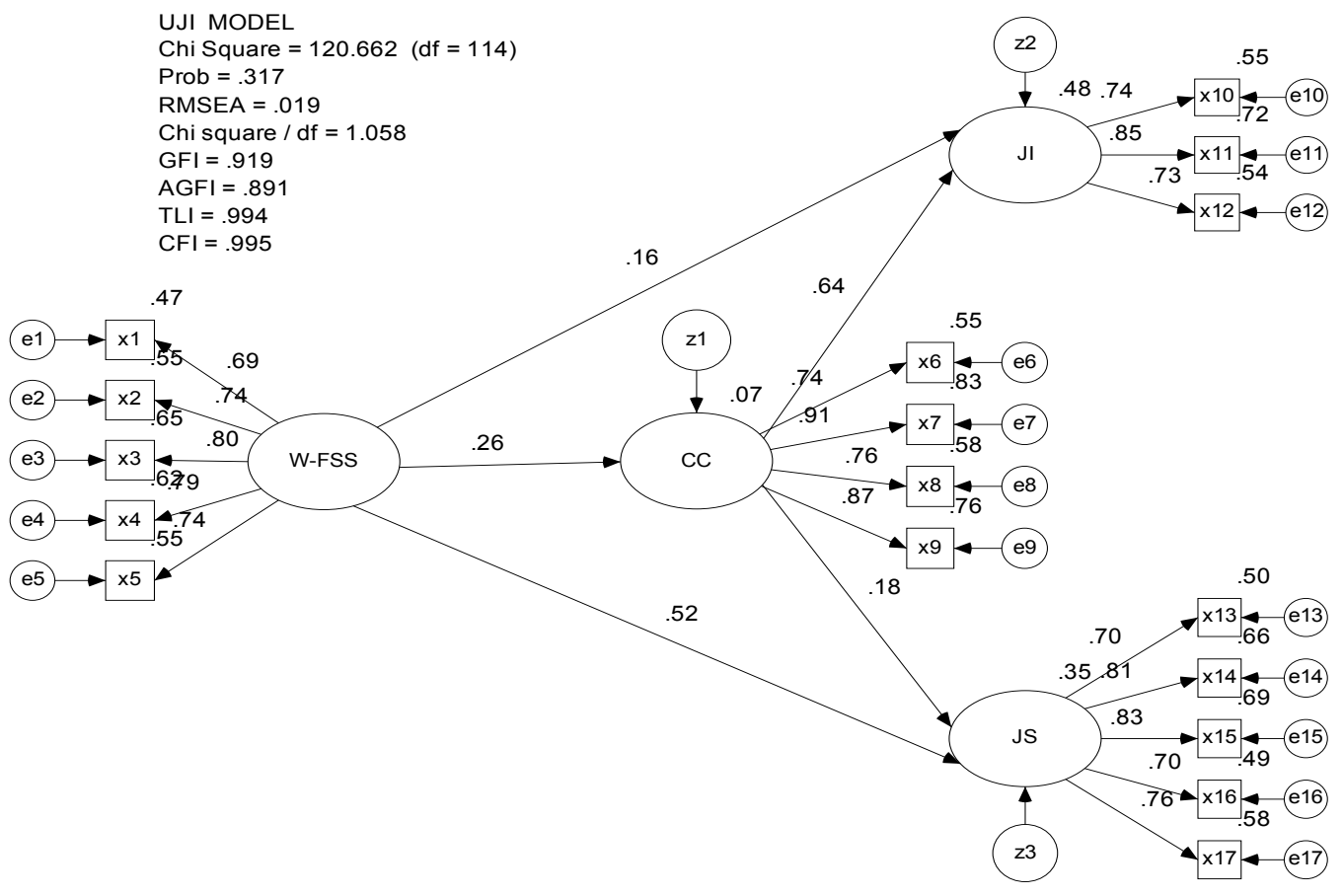

Figure.2 . Results of Testing Structural Equation Modelling (SEM) Full Model

Source: Processed Primary Data, 2016.

Test for the feasibility of SEM full model is tested using Chi-square, CFI, TLI, CMIN/DF and RMSEA which are within the expected range of values, although GFI and AGFI marginally acceptable, as described in following table:

Table 1. Test Results of Goodness-of-Fit

\begin{tabular}{|c|c|c|c|}
\hline $\begin{array}{l}\text { Goodness of } \\
\text { Fit Index }\end{array}$ & $\begin{array}{l}\text { Cut-off } \\
\text { Value }\end{array}$ & Result & $\begin{array}{l}\text { Evaluation } \\
\text { Model }\end{array}$ \\
\hline Chi-Square & Little & 120662 & Good \\
\hline Probability & $\geq 0.05$ & 0317 & Good \\
\hline RMSEA & $\leq 0.08$ & 0019 & Good \\
\hline Chi-square / df & $\leq 2.00$ & 1.0558 & Good \\
\hline GFI & $\geq 0.90$ & 0919 & Good \\
\hline AGFI & $\geq 0.90$ & 0891 & Marginal \\
\hline TLI & $\geq 0.95$ & 0994 & Good \\
\hline CFI & $\geq 0.95$ & 0995 & Good \\
\hline
\end{tabular}

\subsection{Effect of Work-Family Supportive Supervisor on Career Competencies}

Parameter estimation of influence Work-Family Supportive Supervisor for Career Competencies showed coefficient values with the positive direction. Tests of significance influence values obtained $\mathrm{CR}=2,913$ with probability $=0.004<0.05$. Significance value less than

0.05 indicates, that the Work-Family Supportive Supervisor has a significant influence on career competencies. Thus the results of this statistical test successfully supported hypothesis 1 .

\subsection{Effect of Career Competencies on Job Involvement}

Parameter estimation of the influence of career competencies on job involvement showed coefficient values with the positive direction. Tests of significance influence values obtained $\mathrm{CR}=6,404$ with probability $=$ $0.000<0.05$. Significance value less than 0.05 indicated that the career competencies have a significant effect on job involvement. Thus the results of this statistical test successfully supported hypothesis 2 .

\subsection{Effect of Career Competencies on Job Satisfaction}

Parameter estimation of the influence of career competencies on job satisfaction showed coefficient values with the positive direction. Tests of significance influence values obtained $\mathrm{CR}=2,247$ with probability $=$ $0.025<0.05$. Significance value less than 0.05 indicated that the career competencies have a significant effect on job satisfaction. Thus the statistical test is successfully supported hypothesis 3 . 


\subsection{Effect of Work Family Supportive Supervisor on Job Involvement}

Parameter estimation of the influence of the work family supportive supervisor on job involvement showed coefficient values with the positive direction. Tests of significance influence values obtained $\mathrm{CR}=1,983$ with probability $=0.047<0.05$. Significance value less than 0.05 indicates that the work family supportive supervisor has a significant impact on job involvement. Thus the results of this statistical test successfully supported hypothesis 4 .

\subsection{Effect of Work Family Supportive Supervisor on Job Satisfaction}

Parameter estimation of the influence of work-family supportive supervisor on job satisfaction showed coefficient values with the positive direction. Tests of significance influence values obtained $\mathrm{CR}=5,302$ with probability $=0.000<0.05$. Significance value less than 0.05 indicates that the work-family supportive supervisor has a significant impact on job satisfaction. Thus the results of this statistical test successfully supported hypothesis 5 .

\section{Conclusion}

The result of this study showed that work-family supportive supervisor has a positive and significant impact on the nurse career competencies. Better workfamily supportive supervisor will increase the career competencies of nurse at PGI Cikini Hospital Jakarta. Career competencies have a positive and significant impact on nurse's job involvement and job satisfaction. The better career competencies that employees have, will lead to greater job involvement that conducted by nurses. This also applied to job satisfaction of nurse obtained.

Work-Family Supportive Supervisor has a positive and significant impact on nurse job involvement and job satisfaction at PGI Cikini Hospital in Jakarta. The better work-family supportive supervisory gave to nurse, the greater job involvement will be conducted by nurses. Same with job involvement, the better Work-Family Supportive Supervisor gave to the employee, the greater job satisfaction obtained by nurses.

Based on result, $96.30 \%$ percentage of the sample who are women showed that they need a good support and policies to achieve a balance between work and family. When the support and policies are compliance, they will feel safe and satisfied to do their job, which lead to increase their performance.

If the employee get more support from supervisor, they will get other power resources and reduce the level of job responsibilities that involve and impact the family, thereby increasing job satisfaction. This results supported research done in tourist industry [16]. At the same time, organizations and supervisors will restore the psychological identity of their employees, which increase work engagement and organizational commitment [17].

In conclusion, the results of this study support the importance of family supportive supervisory behavior (FSSB) as a resource to assist employees in managing job demands and family. These findings suggest that not only do employees benefit from FSSB as a resource, but the organization also has a possibility to get benefit through positive outcomes such as affective commitment and job satisfaction.

Based on the theories and previous research, current research also convince the future researchers to understand helpfully the process where the FSSB can affect these work and health outcomes. This research will help others researchers and future managers understand the importance of FSSB. This research illustrate the model-based relationship system between FSSB, work-family conflicts and enrichment, and workfamily results. The current study covers the aspect of the model and adds it by including additional variables and explanation processes. Significant direct and indirect effects are found, some supporting the proposed model and another research done in the same setting[ 18, 19]

\section{Limitations and Suggestions}

This study has limitations, where there are 38 questionnaires from a total of 200 questionnaires handicapped. It happened because due to lack of response from the respondents to fulfill the questionnaire research. So that proper questionnaire used in a further analysis in order to produce good results is only 162 questionnaires.

This quantitative research will be more fruitful, if it is accompanied by a qualitative approach. Which is, it still needed to dig how much enthusiastic respondents about every aspect in the variable, so that it will show more accurate results. The uses of open-ended questions are better need to be used to explore the indicators of each variable in depth needs to be done.

In some studies found an answer questionnaire/scale that is almost equal to the value of one indicator on all questionnaires. This can actually be said to be legitimate only. However, when it was discovered that the practice on the field do not match, then there is a possibility that respondents did not give an honest answer. In the future, studies that discuss work-family supportive supervisors should conduct in-depth study with the results from the matching the questionnaire with supervisors, members (employees), and their family members.

\section{References}

1. H. Kong, International Journal of Hospitality Management ,33, 304-309, (2013) doi:10.1016/j.ijhm.2012.09.006

2. L. T. Thomas, and D. C. Ganster, Journal of Applied Psychology, 80(1), 6-15, (1995) doi:10.1037//0021 9010.80.1.6 
3. J. Akkermans, W. Schaufeli, V. Brenninkmeijer, and R. Blonk, Journal of Vocational Behavior,83(3), 356-366, (2013) doi:10.1016/j.jvb.2013.06.011

4. T. J. Clifton, and E. Shepard, International Journal of Manpower,25(8), 714-728, (2004) doi:10.1108/01437720410570036

5. Wulandari, Hubungan Konflik Peran Ganda dengan Stres Kerja Karyawan Wanita di Pusat Administrasi Universitas Indonesia, (Fakultas Ilmu Sosial Ilmu Politik Universitas Indonesia, Depok, 2012)

6. S. Wicaksono, H. A. Bieantri, and A. Nugroho, Jurnal Hospitality dan Manajemen Jasa, 1, 1-20. (2014)

7. R. L. Mathis, and J. H. Jackson, Human resource management. (Thomson/South-Western, Australia, 2003)

8. S. P. Brown, Psychological Bulletin,120(2), 235255, (1996) doi:10.1037//0033-2909.120.2.235

9. Cheung C, TTRA Annual Conference Proceedings, (2009)

10. O. M. Karatepe, and H. Kilic, Tourism Management, 28(1), 238-252. (2007) doi:10.1016/j.tourman.2005.12.019

11. L. E. Ross, and J. S. Boles, International Journal of Hospitality Management,13(2), 155-171, (1994) doi:10.1016/0278-4319(94)90036-1
12. A. Sergeant, and S. Frenkel, Journal of Service Research, 3(1), 18-34, (2000) doi: $10.1177 / 109467050031002$

13. M. H. Yoon, J. H. Seo, and T. S. Yoon, Journal of Services Marketing, 18(5), 395-412, (2004) doi:10.1108/08876040410548311

14. Sugiyono, Statistika untuk Penelitian. (Alfabeta, Bandung, 2001)

15. T. Ferdinand Augusty Metode Penelitian Manajemen: Pedoman Penelitian untuk Skripsi, Tesis dan Disertasi Ilmu Manajemen. (Badan Penerbit Universitas Diponegoro, Semarang, 2006)

16. H. Kong, and Q. Yan, International Journal of Hospitality Management, 41, 133-139, (2014) doi:10.1016/j.ijhm.2014.05.013

17. S. P. Robbins, and M. Coulter, Management: fifth edition. (Qing hua da xue chu ban she, Beijing, 1997).

18. I. B. Siahaan, Hubungan antara Quality of Work Life dengan Keterlibatan Kerja pada Karyawan (2011).

19. A. Zopiatis, P. Constanti, and A. L. Theocharous, Tourism Management, 41, 129-140, (2014) doi:10.1016/j.tourman.2013.09.013 